and D. George (eds.)

\title{
Significance of chaetal arrangement for maldanid systematics (Annelida: Maldanidae)
}

\author{
HARALD HAUSEN ${ }^{1}$ and CHRISTOPH BLEIDORN ${ }^{2}$ \\ ${ }^{1}$ Free University Berlin, Institute for Biology, Zoology, Animal Systematics and Evolution, Königin-Luise-Str. 1-3, \\ D-14195 Berlin, Germany. E-mail: hhausen@zoosyst-berlin.de \\ ${ }^{2}$ University of Potsdam, Institutte for Biochemistry and Biology, Evolutionary biology/Systematic Zoology, Karl- \\ Liebknecht-Str. 25-25, Haus 26, D-14476 Golm, Germany.
}

SUMMARY: Maldanids are usually divided into several subfamilies: Euclymeninae, Lumbriclymeninae, Maldaninae, Nicomachinae, Rhodininae, Clymenurinae, Notoproctinae, and Boguinae. The taxonomy of maldanids and the delimination of these taxa are mainly based on head morphology, total number of segments, chaetal structure, shape of the pygidium, and position of the anus. The maldanid ingroup relationships, as well as the monophyly of the proposed subfamilies, have so far not been investigated. Pilgrim (1977) described a shift of the notopodial chaetal rows from a transverse direction in anterior chaetigers to a more longitudinal one in posterior chaetigers in Clymene torquata (Leidy, 1855) and Euclymene oerstedii (Claparède, 1863), both belonging to the Euclymeninae. We investigated several maldanid species to assess the usefulness of this character for maldanid systematics and used 3D-reconstruction techniques to reveal the complete geometry of the chaetal sacs. Our investigation shows that a shift is apparent in Euclymene, Axiothella, Johnstonia (all Euclymeninae) and Clymenura (Clymenurinae), but absent in species like Maldane sarsi (Malmgren, 1865), Metasychis disparidentata (Moore, 1904) (both Maldaninae) and Petaloproctus borealis Ardwisson, 1906 (Nicomachinae). The shift is not typical for sedentary polychaetes and is apomorphic within maldanid polychaetes. It thus argues for a close relationship between Euclymeninae and Clymenurinae. The investigation of further maldanid species of different subfamilies may shed additional light on maldanid systematics.

Keywords: Annelida, Polychaeta, Maldanidae, systematics, chaetae, chaetal arrangement.

RESUMEN: El SIGNIFICADO DE LA DISPOSICIÓN DE LAS QUETAS EN LA SISTEMÁTICA DE LOS MALDÁNIDOS (ANNELIDA: MALDANIDAE). - Los Maldánidos se clasifican usualmente en ocho subfamilias: Euclymeninae, Lumbriclymeninae, Maldaninae, Nicomachinae, Rhodininae, Clymenurinae, Notoproctinae, y Boguinae. La taxonomía de esta familia está basada en la morfología del prostómio, el número total de segmentos, la estructura de las quetas, la forma del pigidio y la posición del ano. Sin embargo, las relaciones dentro del grupo de los maldánidos , así como la monofília de las subfamilias propuestas, no han sido aún investigadas. Pilgrim (1977) describió en Clymene torquata (Leidy, 1855) y Euclymene oerstedii (Claparède, 1863), ambos pertenecientes a Euclymeninae, un cambio en la orientación de las filas de quetas notopodiales desde una poción transversal en los setígeros anteriores a una posición más longitudinal en los setígeros posteriores. En este trabajo se ha investigado el carácter anterior en diversas especies de maldánidos para ver si podría ser usado en la sistemática del grupo, usando reconstrucciones en tres dimensiones para observar la completa geometría de las bolsas de quetas, Nuestras investigaciones muestran que dichos cambios son aparentes en Euclymene, Axiothella, Johnstonia (todos Euclymeninae) y en Clymenura (Clymenurinae), pero no se presentan en especies como Maldane sarsi (Malmgren, 1865), Metasychis disparidentata (Moore, 1904) (ambas Maldaninae) y Petaloproctus borealis Ardwisson, 1906 (Nicomachinae). Este cambio no es típico de poliquetos sedentarios y es apomorfico dentro de los maldánidos. Todo ello lleva a argumentar una estrecha relación entre Euclymeninae y Clymenurinae. Futuras investigaciones en otras especies de maldánidos pertenecientes a otras subfamilias podría aportar aún mas luz a la sistemática de esta familia de poliquetos.

Palabras clave: Annelida, Polychaeta, maldánidos, sistemática, quetas, disposición de las quetas. 


\section{INTRODUCTION}

Maldanids, the so called "bamboo-worms", comprise a group of tubicolous burrowers. The last thorough review of Maldanidae was made by Arwidsson (1907). In this work the maldanids are subdivided into Euclymeninae, Lumbriclymeninae, Maldaninae, Nicomachinae, and Rhodininae. More recently Clymenurinae (Imajima and Shiraki, 1982) and Notoproctinae (Detinova, 1985) have been proposed. Boguea, a taxon originally described as an oweniid (Hartman, 1945), has also been transferred to Maldanidae (Wolf, 1983). The delimitation of these taxa, and thus the systematics of the family, are mainly based on head morphology, total number of segments, chaetal structure, shape of the pygidium, and position of the anus (Rouse and Pleijel, 2001). The maldanid ingroup relationships, as well as the monophyly of the proposed "subfamilies" have as yet not been investigated.

The value of chaetal characters for systematic studies has been shown for several polychaete taxa (Bartolomaeus, 1998; Hausen and Bartolomaeus, 1998; Hausen, 2005). In Maldanidae the parapodia are usually developed as small extensions of the body wall. The neuropodia bear dentate hooks with a beard. In some taxa thick, spine-like chaetae are present in the anterior chaetigers. In contrast to this the notopodia have rows of different types of capillary chaetae. Pilgrim (1977) described a shift of the notopodial chaetal rows from a transverse direction (seen in relation to the body axis) in anterior chaetigers to a more longitudinal one in posterior chaetigers in Clymene torquata and Euclymene oerstedii, both belonging to the Euclymeninae. This shift is not typical for sedentary polychaetes. In the present study we investigated the presence of this shift in chaetal arrangement to assess its usefulness for maldanid ingroup systematics. For this purpose we examined several taxa of the Euclymeninae,
Clymenurinae, Maldaninae, and Nicomachinae with SEM and light microscopy.

\section{MATERIAL AND METHODS}

Seven different species of Maldanidae have been studied (Table 1). The individuals of Euclymene oerstedii were fixed in Bouin's fluid and stored in $80 \%$ ethanol, whereas all other individuals were fixed in $7 \%$ formol and subsequently stored in the same way. For SEM the specimens were dehydrated in an ethanol series, critical point dried in a Balzers CPD 030 and coated with gold in a Balzers SCD 050. Micrographs were taken using a Hitachi S 450 and a FEI Quanta 200 SEM. For histological investigations the animals were dehydrated in an ethanol series and embedded in Technovit 7100 (Heraeus Kulzer). Serial sections were prepared using a Thermo Shandon Finesse ME rotary microtome. The sections were put on silanized glass slides, stained with $1 \%$ toluidin blue for 1 minute at $60{ }^{\circ} \mathrm{C}$ and mounted with Depex. Images were taken with an Olympus BX 61 dissecting microscope equipped with a SIS Colorview II digital camera in bright field mode. High magnification images were orientated by adjusting them to formerly aligned low magnification images.

\section{RESULTS}

In all maldanids investigated anterior chaetigers show straight transversal rows of capillary chaetae in the notopodia. Usually two types of capillary chaetae form an alternating double row. In the first chaetigers the notopodia are poorly developed and the chaetae emanate from a low elevation of the body surface. In the following chaetigers the notopodia become more and more prominent. The

TABLE 1. - Investigated species, sample locations and methods.

\begin{tabular}{|c|c|c|c|c|c|}
\hline Taxon & Species & Collection site & SEM & $\begin{array}{c}\text { Serial } \\
\text { sections }\end{array}$ & $\begin{array}{c}\text { Stereo } \\
\text { microscope }\end{array}$ \\
\hline Clymenurinae & Clymenura clypeata (Saint-Joseph, 1894) & Roscoff, France & $\mathrm{x}$ & & $\mathrm{x}$ \\
\hline \multirow[t]{3}{*}{ Euclymeninae } & Axiothella $\mathrm{sp}$ * & Blue Ground Range, Belize & $\mathrm{x}$ & & $\mathrm{x}$ \\
\hline & Euclymene oerstedii (Claparède, 1863) & Arcachon, France & $\mathrm{x}$ & $\mathrm{x}$ & $\mathrm{x}$ \\
\hline & Johnstonia duplicata Mackie and Gobin, 1993 & Blue Ground Range, Belize & $\mathrm{X}$ & & \\
\hline \multirow[t]{2}{*}{ Maldaninae } & Maldane sarsi (Malmgren, 1865) & Kristineberg, Sweden & & $\mathrm{x}$ & $\mathrm{x}$ \\
\hline & Metasychis disparidentata (Moore, 1904) & Santa Monica Bay, CA, USA & $\mathrm{x}$ & & $\mathrm{x}$ \\
\hline Nicomachinae & Petaloproctus borealis Ardwisson, 1906 & Concarneau, France & & & $\mathrm{x}$ \\
\hline
\end{tabular}

*new species, description in preparation 

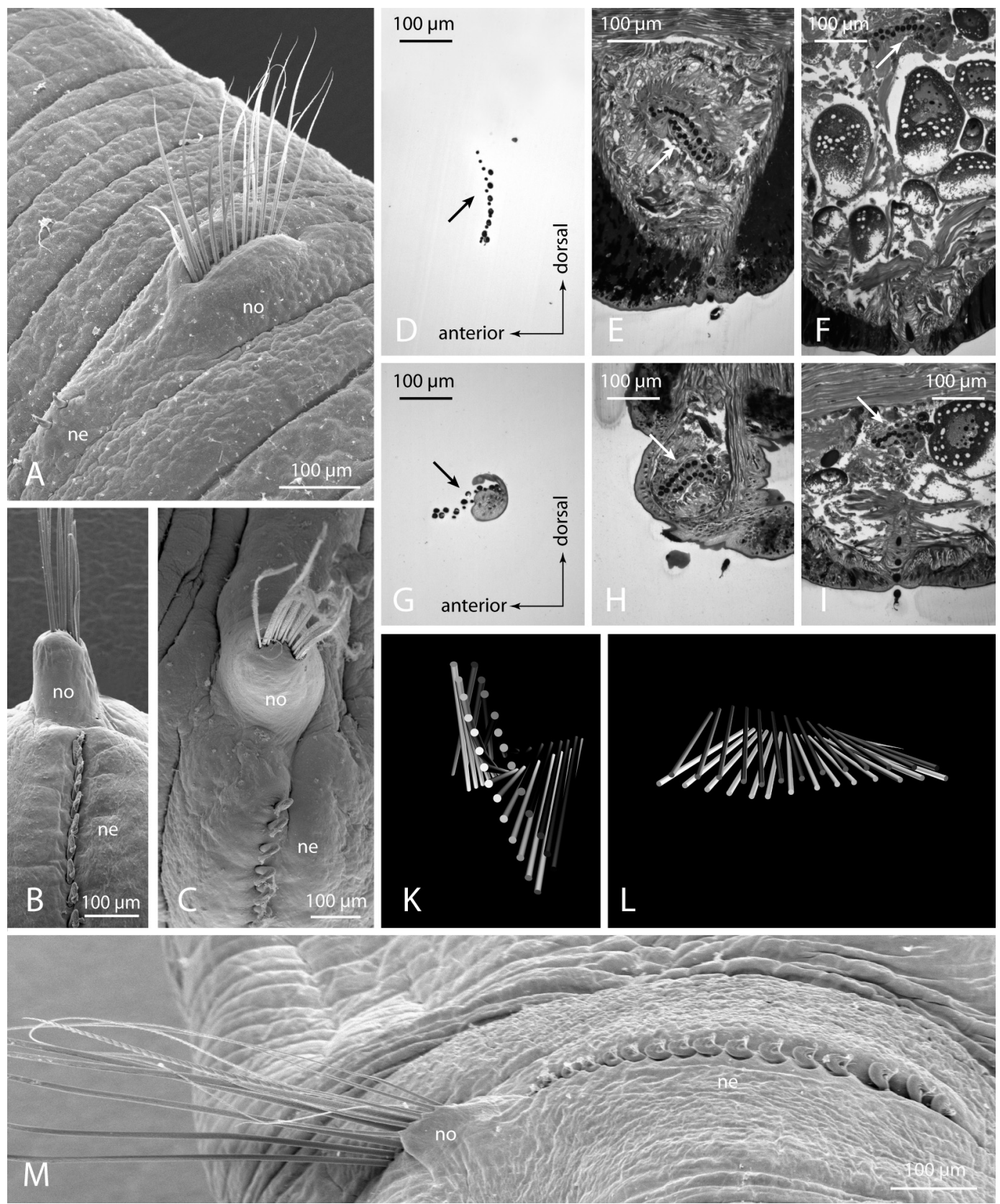

FIG. 1. - A, Axiothella sp. (Euclymeninae), parapodium of chaetiger 1; B, Johnstonia duplicata (Euclymeninae), chaetiger 19; C, Axiothella sp. (Euclymeninae), chaetiger 16. D-L, Euclymene oerstedii: D, notopodial chaetae of 6th chaetiger at body surface level; E, midlevel of chaetal sac; F, base of chaetal sac; G, notopodial chaetae of 3rd prepygidial chaetiger above body surface; H, midlevel of chaetal sac; I: base of chaetal sac; K, schematic reconstruction of 6th notopodium; L, schematic reconstruction of 3rd prepygidial notopodium; M, Metasychis disparidentata (Maldaninae), chaetiger 19; ne: neuropodium; no: notopodium. Arrows point to the notopodial chaetal rows.

neuropodia are low tori throughout the body and bear in all investigated specimens a row of longshafted hooks with a prominent beard structure. The first three anterior chaetigers always show a lower number of chaetae and may further differ in bearing acicular spines instead of hooks with beards. The chaetae of anterior noto- and neuropodia are aligned in one common, transverse plane in all specimens investigated (Fig. 1A). This pattern of chaetal arrangement remains the same for all following chaetigers in Maldane sarsi (Maldaninae), Metasychis disparidentata (Maldaninae) (Fig. 1M) and Petaloproctus borealis (Nicomachinae). A distinct pattern of chaetal arrangement can be observed for Clymenura clypeata (Saint-Joseph, 1894) (Clymenurinae), Euclymene oerstedii, Axiothella sp., and Johnstonia duplicata Mackie and Gobin, 1993 (all Euclymeninae). From the midbody region 
onwards in the notopodia a stepwise transformation to a bent, longitudinally directed double row is observed. Thereby the posterior chaetae shift to a dorsal position and the anterior chaetae to a ventral position. Finally in posterior chaetigers the notopodial rows are perpendicular to the neuropodial rows of hooks (Fig. 1B, C). The investigation of the properly aligned serial sections of Euclymene oerstedii revealed the three dimensional structure of the chaetal sacs of the notopodia (Fig. 1 D-F, K). The chaetae of each notopodial row are not on the same plane, and their tips are on a plane twisted about $90^{\circ}$ compared to that of the bases of the chaetae. The bases thus form a longitudinal row and the base of the chaeta with the most ventral position above the body surface has the most caudal position. New chaetae are only formed on the ventral (resp. caudal) position of the transversal rows. An identical arrangement was observed in Maldane sarsi in both anterior and posterior notopodia. In contrast to this the notopodial rows of posterior chaetigers in $E$. oerstedii show a significant difference. Here the chaetal rows are not twisted (Fig. 1G-I, L). The chaetae remain arranged in a longitudinal direction from their tips down to the base of the chaetal sac. New chaetae always enter the rows from a caudal position.

\section{DISCUSSION}

The maldanid subtaxa as established by Arwidson (1907) and later used in Fauchald (1977) are mainly distinguished by the morphology of the head and the pygidium. The Rhodininae lack cephalic and anal plates and the neuropodial hooks are arranged in double rows; the Lumbriclymeninae also lack both plates, but their hooks are in single rows. In the Nicomachinae an anal plate is present. Two plates are present in Euclymeninae and Maldaninae. The latter are unique in possessing a dorsal anus, whereas Euclymeninae have a terminal anal position. Later, Imajima and Shiraki (1982) erected Clymenurinae, which were formerly included within Euclymeninae by Arwidsson (1907). They are distinguished from the Euclymeninae by their large triangular glandular shield on segment 8 . However, the monophyly of these maldanid subgroups has never been tested and hypotheses on the relationships between them have never been proposed (Rouse and Pleijel, 2001).
In this study we investigated the chaetal arrangement to estimate its potential to unravel maldanid relationships. In all the examined notopodia of Euclymeninae and Clymenurinae the arrangement differs between anterior and posterior chaetigers. Whereas anterior notopodia show transverse rows the posterior ones show longitudinal rows. In all other maldanid taxa examined the posterior and anterior notochaetae are arranged in transverse rows. New chaetae are always formed at the ventral edge of the rows. The same arrangement is known for many sedentary polychaetes (Hausen, 2005). Notopodial transverse rows with a ventral formative site have been shown throughout the body for members of Spionidae (Hausen and Bartolomaeus, 1998; Radashevsky and Fauchald, 2000), Capitellidae (Schweigkofler et al., 1998), Magelonidae, Paraonidae, and Cirratulidae (Hausen, 2001). Sabellidae irrespective of the chaetal inversion also have tranverse rows with a ventral formative site within their notopodia (Bartolomaeus, 1995; Bartolomaeus, 2002) and this is also found in Sabellariidae and Terebellidae (unpublished data). The histological data of Euclymene oerstedii revealed that the rows of chaetae in anterior chaetigers form anteroposterior rows at the level of the bases and thus are twisted on their course up to the body surface. These findings are congruent with those of Pilgrim (1977). In posterior notopodia of Euclymene oerstedii the chaetae are instead arranged in the form of a fan in a single plane and the bases are aligned in the same anterorposterior direction as the upper parts of the chaetae. This situation is not known for other sedentary polychaetes and thus most probably represents an apomorphic condition and argues for a close relationship between Euclymeninae and Clymenurinae within Maldanidae, whose other members, so far investigated, show the plesiomorphic condition.

Defining monophyletic groups is a prerequisite for every systematic analysis of higher level relationships. As mentioned above the monophyly of maldanid subtaxa ("subfamilies") has never been tested and the monophyly of some of them seems highly questionable. For example, both Lubriclymeninae and Rhodininae are characterised by the absence of head and anal plates and only separated by the arrangement of the rows of uncini. Since one of these two characters (double vs. single rows) must represent the plesiomorphic condition it cannot be used to define a subclade, even in the 
unlikely case that Lubriclymeninae and Rhodininae together do form a clade. As a perspective for further systematic studies of maldanid relationships we investigated the value of chaetal arrangements as a phylogenetic character. It seems that this character can be polarised using outgroup comparison and that it is possible to define a monophyletic group that includes at least Euclymene and Clymenurinae although even this should be severely tested within a cladistic framework.

\section{ACKNOWLEDGEMENTS}

We are thankful to the Smithsonian Institution for supporting a collecting trip to Carrie Bow Cay field station and for comments of D. Eibye-Jacobsen and another reviewer, which improved the manuscript.

\section{REFERENCES}

Arwidsson, I. - 1907. Studien über die skandinavischen und arktischen Maldaniden. Zool. Jb., Abt.f. Syst., Suppl. 9: 1-308.

Bartolomaeus, T. - 1995. Structure and formation of the uncini in Pectinaria koreni, Pectinaria auricoma (Terebellida) and Spirorbis spriorbis (Sabellida): implications for annelid phylogeny and the position of the Pogonophora. Zoomorphology, 115: 161-177.

Bartolomaeus, T. - 1998. Chaetogenesis in polychaetous Annelida - significance for annelid systematics and the position of the Pogonophora. Zoology, 100: 348-364.
Bartolomaeus, T. - 2002. Structure and formation of thoracic and abdominal uncini in Fabricia stellaris (Müller, 1774) - implication for the evolution of Sabellida (Annelida). Zool. Anz., 241: $1-17$

Detinova, N.N. - 1985. Taxonomy, composition and distribution of polychaetes of subfamily Lumbriclymeninae (Maldanidae). Issledovaniya Fauny Morei, 1985: 25-29.

Fauchald, K. - 1977. The polychaete worms. Definitions and keys to the orders, families and genera. Nat. Hist. Mus. LA County Sci.Ser. 28: 1-188.

Hartman, O. - 1945. The marine annelids of North Carolina. Duke Univ. Mar. Stat. Bull., 2: 1-54.

Hausen, H. - 2001. Untersuchungen zur Phylogenie "spiomorpher" Polychaeten (Annelida). Ph. D. thesis, Univ. Bielefeld, Logos Verlag, Berlin.

Hausen, H. - 2005. Chaetae and chaetogenesis in polychaetes (Annelida). In: G. Purschke and T. Bartolomaeus (eds.), Morphology, Molecules, Evolution and Phylogeny in Polychaetes and Related Taxa, pp. 37-52. Hydrobiol, vol. 535/536.

Hausen, H. and T. Bartolomaeus. - 1998. Setal structures and chaetogenesis in Scolelepis squamata and Malacoceros fuliginosus (Spionidae, Annelida). Acta Zool., 79: 149-161.

Imajima, M. and Y. Shiraki. - 1982. Maldanidae (Annelida: Polychaeta) from Japan (Part 1). Bull. Nat. Sci. Mus., Tokyo, A, 8: 7-46.

Pilgrim, M. - 1977. The functional morphology and possible taxonomic significance of the parapodia of the maldanid polychaetes Clymenella torquata and Euclymene oerstedii. J. Morph., 152: 281-302.

Radashevsky, V.I. and K. Fauchald. - 2000. Chaetal arrangement and homology in spionids (Polychaeta: Spionidae). Bull. Mar. Sci., 67(1): 13-23.

Rouse, G.W. and F. Pleijel. - 2001. Polychaetes. University Press, $354 \mathrm{pp}$. Oxford.

Schweigkofler, M., Bartolomaeus, T. and L. von Salvini-Plawen. 1998. Ultrastructure and formation of hooded hooks in Capitella capitata (Capitellida, Annelida). Zoomorphology, 118: $117-128$

Wolf, P.S. - 1983. A revision of the Boguidae Hartman and Fauchald (1971), and its reduction to Boguinae, a subfamily of Maldanidae (Polychaeta). Proc. Biol. Soc. Wash., 96: 238-249.

Received September 9, 2004. Accepted May 11, 2005. 